JURNAL AL BAYAN: JURNAL JURUSAN PENDIDIKAN BAHASA ARAB

p-ISSN 2086-9282 | e-ISSN 2549-1229

\title{
Arabic Learning by Using Hybrid Learning Model in University
}

\author{
Akla \\ Arabic Education Study Program Institut Agama Islam Negeri Metro, Indonesia
}

\begin{abstract}
Article History:
Received : November 20, 2020

Revised : December 27, 2020

Accepted : January 30, 2021

Published : June 01, 2021
\end{abstract}

\section{Keywords:}

Arabic Language; Hybrid Learning; Language Mastery; Learning

Motivation

*Correspondence Address: akla@metrouniv.ac.id

\begin{abstract}
The Arabic language learning for university students in University is faced by various problems that impact the lack of language proficiency. Some problems faced by university students come from negative learning attitudes, low motivation, unhappy feelings toward the Arabic course that tends to be boring as well as a non-supportive language environment. The use of Hybrid Learning approach in Arabic language learning was done by strengthening students' physical and mental state. This research aims to: (1) analyze the Arabic language learning by using Hybrid Learning Approach, (2) analyze lecturers' technology literacy level in deciding the success of the learning process (3) analyze the effectiveness of Hybrid learning model on students' learning outcomes in Arabic language. This study applied the Mixed-Method Research to examine students' Arabic proficiency and learning process by using Hybrid Learning approach. The research respondents in this study are college students who take an Arabic language subject that consist of 80 students in each College. The data collection technique used in this research is a test, questionnaire, and interview. The use of Hybrid learning in Arabic language learning can improve students' positive attitude and learning motivation. Besides, this also can enhance students' Arabic language skills. The significance of the research is to solve various problems of Arabic language learning faced by lecturers. The implementation of Hybrid learning can create an effective learning environment that can enhance Arabic language skills. This research result can be applied by Arabic language lecturers to handle various problems regarding attitude and learning motivation.
\end{abstract}

\section{Introduction}

In several universities, Arabic learning has to deal with any problems that might cause the students not achieve the specified language mastery. Some of the problem might be caused by negative attitudes in learning, low learning enthusiasm, the dislike of Arabic courses which is stimulated by monotonous and boring way and the language environment is not supportive. Dhian also stated that the problem of students in achieving a good result is caused by low learning motivation, undisciplined learning 
attitudes, low interest in subject matter, unsupportive school environment, unsupportive family and community environment ${ }^{1}$.

These problems cause negative impact for Arabic skill mastery. The study of W. Azura et al. argued that there are $45 \%$ of students in University are less proficient in Arabic, 55\% of students are not really proficient in Arabic even though the most of the students have been learning Arabic for 6 years $^{2}$. Erwhintian and Basid also argued that the students' ability in speaking Arabic was still low. Their speaking ability was considered as low is caused by lack of vocabulary (40\%), the difficulty in expressing vocabulary and sentences (23\%), lack of confidence (27\%), limited time (3\%), and lack of environmental support $(7 \%)^{3}$.

The problem of learning Arabic for students in University was caused by two main problems, namely language problem and process of learning problem. Language problem is the problem in mastering some Arabic skills such as vocabulary, grammar, reading, and speaking to express the thought. The problem of the learning process includes monotonous learning and learning models that are incompatible with the characteristics of students who come from various educational backgrounds. In addition, not all Arabic teachers are graduates of master's degrees in Arabic language education, the measurement of Arabic language competency standards are not clear, and the use of media is irrelevant ${ }^{4}$.

Nowadays, the study of Arabic language learning among university students tends to examine three main issues. First, a study that looks at the importance of the role of Arabic language teachers by optimizing the use of strategies, methods and learning media that are relevant to the characteristics of the learning material ${ }^{5}$. The use of relevant

\footnotetext{
${ }^{1}$ Anggraini Dhian, "Identifikasi Kesulitan Belajar Siswa Kelas V SD Negeri Sosrowijayan Kota Yogyakarta", Jurnal Pendidikan Guru Sekolah Dasar 5, no. 3 ( 2016): 169-182.

${ }^{2}$ Wan Azura, Wan Ahmad, dan Lubna Abd Rahman, "Pembelajaran bahasa Arab di Universiti Sains Islam Malaysia ( USIM )", Prosiding, (2007):1-14.

3 Ifi Erwhintiana dan Abdul Basid, "Analisis Diagnostik Kesulitan Belajar Maharah Kalam Mahasiswa Bahasa dan Sastra Arab 2017", Prosiding Seminar Nasional Bahasa Arab Mahasiswa I Tahun 2017 HMJ Jurusan Sastra Arab Fakultas Sastra Universitas Negeri Malang no. 5 (2017): 109-124.

${ }^{4}$ Sahkholid Nasution dan Zulheddi Zulheddi, "Pengembangan Model Pembelajaran Bahasa Arab Berbasis Teori Konstruktivisme Di Perguruan Tinggi", Arabi : Journal of Arabic Studies 3, no. 2 (2018): 121.

${ }^{5}$ Mastura Arshad dan Kaseh Abu Bakar, "Penggunaan Strategi Pembelajaran Kemahiran Bertutur Bahasa Arab: Kajian Di Pusat Asasi UIAM", Persidangan Kebangsaan Pengajaran Dan Pembelajaran Bahasa Arab (2012); Nur Khadijah, Abu Bakar, dan Zamri Arifin, "Penggunaan Strategi Belajar Bahasa dalam Pembelajaran Bahasa Arab Sebagai Bahasa Kedua: Satu Sorotan", Prosiding Seminar Pengajaran \& Pembelajaran Bahasa Arab (2014); Ahmad Zamri dan Abdullah Ibtisam, "Metode Pengajaran Dan Pembelajaran Bahasa Arab Berasaskan Empat Kemahiran", Prosiding Seminar Pengajaran \& 
strategies, methods and media will encourage students to easily master the language material being taught. Some considered that the presence of professional teachers had a significant effect on student learning activities in achieving Arabic language skills ${ }^{6}$. Second, studies that examine the approach to Arabic learning. The approach model used in a variety of ways will help students improve language mastery ${ }^{7}$. An attractive approach model is considered to have an influence on the learning atmosphere which can generate concentration and learning motivation. High concentration and motivation to learn will help the students to master the learning material ${ }^{8}$. Third, the study that researches Arabic learning with an online learning model can help students to master Arabic vocabulary. In addition, the online learning model can increase students' self independence, help students develop their potential and encourage students to be skilled ${ }^{9}$. From the three trends of previous research, it appears that Hybrid Learning model in Arabic learning has not been studied specifically.

This study complements the previous studies which tend to ignore the use of a combined model that combines face-to-face, offline and online learning as a learning system. This combined learning model is known as Hybrid Learning. Hybrid Learning model is a process of acquiring student skills and knowledge developed in instructional design by integrating traditional learning with web-based online models both on the

Pembelajaran Bahasa Arab (2014); Abdul Rahman Awatif dkk., "Penguasaan Bahan Bacaan Bahasa Arab Melalui Teknik Membaca SQ3R", Journal of Social Sciences and Humanities 13, no 4 (2016): 68-80.

${ }^{6}$ Amatullah Faaizatul Maghfirah, "Kreativitas Dosen dalam Meningkatkan Minat Belajar Bahasa Arab Mahasiswa di IAIN Surakarta", Academica : Journal of Multidisciplinary Studies 1, no. 1 (2017): 1933; Alinis Ilyas, "Dosen Bahasa Arab dan Kompetensinya", Jurnal Al Bayan 10, no. 1 (2018): 86-102.

${ }^{7}$ Een Tur'aeni., "Implementasi Pendekatan Fungsional dalam Pembelajaran Bahasa Arab di MTSN Al- Hilal", Jurnal Shaut Al- 'Arabiyah 7, no.2 (2011): 173-92; Subur, "Pendekatan dan Strategi Pembelajaran Bahasa Arab", Jurnal Insania 11, no. 2 (2016): 164-75; Supardi, "Model Pembelajaran Bahasa Arab Terpadu di Perguruan Tinggi Keagamaan Islam Negeri", Jurnal Lisania 2, no. 1 (2018): 1327; Shafruddin Tajuddin, "Pengembangan Model Pembelajaran Bahasa Arab", Jurnal Perameter 29, no. 2 (2016): 200-215.

8 Muhammad Tunde Yaqub, "Developing Speaking Skill in Arabic Learners: A Proposal for Integration of Product and Process Approaches", European Scientific Jounal 8, no. 29 (2012): 140-49; Suo Yan Mei, Suo Yan Ju, dan Ayishah Binti Mohd, "Cooperative Learning Strategy in teaching Arabic for Non Native Speakers", European Journal of Social Sciences Education and Research 11, no. 2 (2017): 261-266; Muhamadul Bakir Hj. Yaakub, "Teaching Arabic as a Second Language: An Evaluation of Key Word Method Effectiveness", Jurnal Teknologi 46, no. 1 (2007): 61-72; Ismail Suardi Wekke, "Arabic Teaching and Learning: A Model from Indonesian Muslim Minority", Procedia - Social and Behavioral Sciences (2015): 286-90.

${ }^{9}$ Nuril Mufidah dkk., "Hybrid Learning Dalam Pembelajaran Kosa Kata Bahasa Arab pada Anak Berbantuan Media, Journal Al-Mudarris 2, no. 1 (2019): 40; Nur Hayati dan Mualim Wijaya, "Pengelolaan Pembelajaran melalui Blanded Learning dalam Meningkatkan Receptive Skill Peserta Didik di Pondok Pesantren", Jurnal Palapa 6, no. 2 (2018): 1-18. 
aspects of the media and tools used as well as the learning models and strategies ${ }^{10}$. The model is done by collaborating face-to-face learning with online technology management ${ }^{11}$. The system of combining face-to-face and online learning creates a unique, structured and meaningful learning system ${ }^{12} .30 \%-70 \%$ of learning instructions are delivered through online technology ${ }^{13}$. In addition, the learning model is carried out by combining direct instruction, indirect instruction, collaborative learning, individual learning and online-based learning ${ }^{14}$. Learning with Hybrid Learning model requires a comprehensive change in learning methods by accommodating new technology. Teachers are required to make strategic adjustments in each learning process ${ }^{15}$. The presence of a teacher is very important to ensure all learning components can be functional optimally ${ }^{16}$. In addition, the level of teaching technology literacy plays an important role in the effective use of technology. The better the teaching technology literacy level, the better the message communicated to students ${ }^{17}$.

Hybrid Learning model provides space for teachers to reflect on their ability to respond to students' development and change in the form of collaborative learning designs between traditional learning and online learning that are in accordance with student characteristics ${ }^{18}$. The integration of innovative strategies and technology in this model is adapted to the demands of student development by utilizing multimedia technology, streaming video, virtual classes, voice messages, email, conference calls,

${ }^{10}$ Blanka Frydrychova Klimova dan Jaroslav Kacetl, "Hybrid Learning and its Current Role in the Teaching of Foreign Languages", Procedia - Social and Behavioral Sciences 182 (2015): 477-81; Fu Lee Wang, Joseph Fong, dan Reggie C. Kwan, "Advanced Tools, Technologies, And Applications". Handbook Of Research On Hybrid Learning Models (2009):7.

${ }^{11}$ Robin Castro, "Blended Learning in Higher Education: Trends and Capabilities", Education and Information Technologies Journal 24, no. 4 (2019): 25-46.

12 Paolo Boccardelli Dkk., Learning And Innovation In Hybrid Organizations: Strategic And Organizational Insights, Learning And Innovation In Hybrid Organizations (2017), 9.

${ }^{13}$ Shu Chen Yen Dkk., "Learning Online, Offline, And In-Between: Comparing Student Academic Outcomes And COurse Satisfaction In Face-To-Face, Online, And Blended Teaching Modalities", Education and Information TechnologiesJournal 23, no. 5 (2018): 41-53.

${ }^{14}$ Wahyu Setyaningrum, "Blended Learning: Does it Help Students in Understanding Mathematical Concepts", Jurnal Riset Pendidikan Matematika 5, no. 2 (2018): 44-53.

15 Annelies Raes dkk., "A Systematic Literature Review on Synchronous Hybrid Learning: Gaps Identified", Jurnal Learning Environments Research (2019): 1-22.

${ }^{16}$ Abbas Pourhosein Gilakjani dan Narjes Banou Sabouri,"Teachers’ Beliefs in English Language Teaching and Learning: A Review of the Literature", Jurnal English Language Teaching 10, no. 4 (2017): 78.

${ }^{17}$ Jorge Reyna, Jose Hanham, dan Peter Charles Meier, "A framework for Digital Media Literacies for Teaching and Learning in Higher Education", Jurnal E-Learning and Digital Media 15, no. 4 (2018): 176-90.

18 V Ross et.al, "Hybrid Learning Model-A Framework for Teaching and Learning Practice", International Journal of Emerging Technologies in Learning 3, no. 1 (2008): 12-17. 
online animated text ${ }^{19}$. Learning media support is absolutely necessary in order to expedite the learning process ${ }^{20}$.

The use of Hybrid Learning in university is currently an alternative solution to the problem of low language mastery which is triggered by a lack of concentration and negative attitudes in learning. This study implicitly describes the Arabic learning process with a participatory Hybrid Learning model by combining face-to-face, offline and online learning. In line with this objective, there are three questions that can be formulated; (1) How can learning Arabic use Hybrid Learning model in Higher Education? (2) How can the level of technological literacy in teaching and students determine the success of learning Arabic? (3) How does Hybrid Learning model affect students' Arabic proficiency?

The answer of this question becomes a discussion that provides an understanding of the potential of Hybrid Learning model in solving problems experienced by university students in Arabic learning. This paper is based on three arguments. First, the use of Hybrid Learning model in learning makes it easier for students to improve their Arabic language skills. This is possible because Hybrid Learning model provides a learning atmosphere that combines a fun face-to-face, offline and online system. In addition, the characteristics of Hybrid Learning model are in line with the age of college students. Second, the success of learning based on Hybrid Learning model is largely determined by professional teachers who are able to design learning from planning, processing to evaluation based on Hybrid Learning model. Third, the success of Arabic learning by using Hybrid Learning model will not be achieved without an adequate level of technological literacy in the teacher. Teachers as the learning facilitators must have the ability to utilize technology content required during the offline and online learning process. At least, Arabic teachers have a standard of mastery of technology that is used as a reference in carrying out learning activities.

\section{Method}

This study analyzes the use of Hybrid Learning model for university students to improve their Arabic language skills. The choice of Hybrid Learning as a learning model

${ }^{19}$ Kaye Thorne, Blended Learning: How to Intergrate Online Learning and Traditional Learning (2003), 23-25.

${ }^{20}$ Caroline Haythornthwaite dan Richard N.L. Andrews, E-learning Theory and Practice, SAGE Publications Inc (2011), 262. 
is based on the consideration that the characteristics of Hybrid Learning model are in accordance with the characteristics of students in university who are able to learn independently. The research location is the State Islamic Institute (IAIN) Metro dan Islamic Institute Ma'arif NU (IAIM NU), Metro. The selection of research sites was based on the consideration that both universities had Arabic language teaching programs, had adequate infrastructure, teachers who were qualified in their fields but still experienced various obstacles in Arabic learning.

This study used a Mixed Method Research, a combination to test students' Arabic language skills and also the learning process. This study did not only analyzed about the level of transformation of students' Arabic language skills after the use of Hybrid Learning model, it also analyzed the process of using Hybrid Learning model in Arabic learning. The implementation of this combined method is focused on data collection, data analysis which was carried out in a series of studies. The primary data used were data on the level of Arabic proficiency, data on the level of technological literacy for lecturers and students and data about the learning process using Hybrid Learning model. The secondary data in this study were the data of student learning attitudes during the learning process using Hybrid Learning model. The respondents of this research were 50 students taking Arabic courses, amounting to 50 students from each university. The selection of respondents was carried out randomly on respondents who had the same characteristics in Arabic language skills. The number of respondents selected at each university is divided into 2 groups as the experimental group and the control group. The experimental group was taught using Hybrid Learning model, and the control group was taught using the offline model only. Apart from students, Arabic teachers are also respondents in this study.

Data collection techniques are tests, questionnaires, and interviews. The test instrument is aimed at students to get data about the level of Arabic proficiency after participating in the lesson. The questionnaire instrument was aimed at lecturers and students to obtain data on the level of technological literacy and student learning attitudes. The interview instrument is aimed at student activities in order to obtain data on the learning implementation process and student learning attitudes during the use of Hybrid Learning model.

Qualitative data analysis and quantitative data analysis were used in this research. Qualitative analysis was carried out in several stages; First, do coding the researchers' 37 | Jurnal Al Bayan: Jurnal Jurusan Pendidikan Bahasa Arab, 13 (1): 32-52 (2021) 
note in classroom observations. Second, create a concept from data that has not changed. Third, create categories from the results of interviews and field qualitative data obtained. Fourth, the categories compiled are hypothesized. Fifth, produce an analysis that is ready to be tested. The quantitative data analysis was carried out by using the prerequisite test, they are homogeneity test and the normality test, which was then followed by the t-test to determine the level of mastery of Arabic after using Hybrid Learning model. Descriptive analysis was also carried out to see the level of student learning motivation.

\section{Result and Discussion}

\section{Hybrid Learning Model for Arabic Learning}

Arabic learning in IAIN Metro and IAIM NU Metro City has been using Hybrid Learning model for one semester. The instructor's learning process combines various web-based and face-to-face technologies to achieve the goal of Arabic language skills. The use of technology in learning combines e-learning technology, video streaming, films, virtual classes with face-to-face learning. The learning environment is designed by teachers with a pattern; online-face-to-face-independent learning, it was about $40 \%$ for face-to-face learning and $60 \%$ for online learning in a single learning system. Face-toface learning uses several strategies and methods, namely Direct Methods, Audio-visual Methods, Audio-lingual Methods, Grammar Translation Methods, question and answer methods, assignment methods and cooperative learning strategies. The implementation of face-to-face learning is carried out in classrooms with a model of communication and direct interaction with students. Direct interactions carried out by lecturers are used to convey learning objectives and material for mastery of language skills (listening, speaking, reading and writing) and language elements (vocabulary and grammar).

In online learning, there have been various interactions, such as student interaction with technological interfaces that are tied to instructional information, student interaction with lecturers and student interaction with other students. Student interaction with technological interfaces leads to an independent learning process that is not bound by time and students come into contact with the text a lot. Online learning sources used were electronic books, electronic journals, videos, forum discussions and direct questions and answers. The instructional video used contains materials to strengthen listening and speaking skills. The material presented in the learning includes language skills, such as 
listening, reading, and writing. In addition, the material presented is in the form of language grammar and vocabulary.

Based on the analysis of student attitudes during implementing Hybrid Learning model in the learning process, there are several dimensions of attitude, such as tendency, motivation, anxiety and self-concept. The tendency of students to take part in the learning process was $92.7 \%$ of students showed a positive attitudes and $7.3 \%$ of students showed a attitudes tendency. The tendency of positive attitudes shown by students is in the form of students' willingness to follow all instructions and learning processes given by the lecturer, both offline and online. Students also show a responding attitude which is characterized by feeling happy when the learning process takes place. Students show a possitive attitude during answering every question, doing the assigned assignment with full of enjoyment. In addition, students showed an attitude of commitment which was marked by a willingness to increase vocabulary mastery with various strategies, study reading texts and complete assignments according to the guidelines. Another positive attitude shown by students is they apply their knowledge which was obtained from online class even after the lesson time is over, such as practicing to speak Arabic and writing a simple essay. Speaking exercises are carried out with a time and place commitment such as the agreement of students for 3 days in a week to speak Arabic both in the learning class and after the learning time. Afterwards, writing exercises are carried out intensively outside of learning. The writing material also varies, from daily activities to free writing.

Some students show negative attitudes in learning. Negative attitudes are shown when the students were indifference to the assignment, being anxious for mastering a lot of vocabulary, not being able to speak Arabic and encouraging the other students to not attend online classes and not responding to assign the task. The dimensions of motivation in learning are $78.2 \%$ of students have very high motivation, $11.3 \%$ of students have high motivation, $3.2 \%$ of students have moderate motivation and $7.3 \%$ of students have low motivation. Students who have high motivation show a positive attitude in learning. Otherwise, students who have low motivation show negative attitudes in learning.

Self-concept dimension appears in students' learning attitudes. To master Arabic skills, students have made every effort to perfect their abilities. The learning experience given by the lecturer in the aspects of mastery of vocabulary, grammar, speaking and writing can build the self-concept of each student. It can be seen from the way they get new vocabulary and assemble them into sentences and then express them either in 39 | Jurnal Al Bayan: Jurnal Jurusan Pendidikan Bahasa Arab, 13 (1): 32-52 (2021) 
writing or orally. Students' self-concept is obtained from the learning environment. The ability to speak Arabic that is obtained from the learning environment conditioned by the lecturer has built self-concept in students which continues to develop in accordance with the increasing Arabic skills achieved by each student.

The Level of Technological Literacy of Teachers and Students Determines the

\section{Success of Teaching Arabic}

The level of technological literacy determines the success of learning Arabic for students. The success of technological literacy is supported by three main factors, namely (1) the availability of learning infrastructure in university (2) lecturers who are competent in their fields and have high responsibility for the learning problems. (3) students' motivation in Arabic learning. Based on the observations on infrastructure in the university, it is found that the availability of electricity and WiFi are very supportive. In each study room there is an LCD projector, comfortable classrooms, healthy air circulation, sound system, external hard disk and fans in each study room. Each lecturer and student has a laptop. The availability of this facility really supports the implementation of Hybrid Learning model in Arabic learning.

The learning process with Hybrid Learning Model in Arabic learning requires lecturers who have an adequate level of technological literacy and are competent in Arabic learning. The results of the questionnaire analysis of Arabic language lecturers at IAIN Metro and IAIM NU Metro, it is known that Arabic language lecturers at these two institutions have good leadership, have high responsibility for the learning problems. In addition, the lecturers understand digital literacy such as utilizing smart phones with all their features, utilizing laptops, utilizing to design attractive visual and audio-visual learning media using computers or laptops, compiling learning designs based on digital technology, and having a good emotional intelligence and high level of cooperation. This ability makes lecturers have no obstacles in implementing Hybrid Learning model. The results of data analysis show the level of technological literacy of Arabic language lecturers at a high level with mean score is 80.13 and 77.06 (table.1). 
Table 1. Technology Literacy Level of Lecturers in University

\begin{tabular}{lrrrrr}
\hline & N & Minimum & Maximum & Mean & Std. Deviation \\
\hline IAIN Metro Lampung & 5 & 62.00 & 96.00 & 80.1333 & 9.89853 \\
IAIM NU Kota Metro & 5 & 62.00 & 90.00 & 77.0667 & 8.27618 \\
& 5 & & & & \\
\hline
\end{tabular}

From table 1, it is known that the mean value of the technology literacy level of Arabic lecturers at IAIN Metro Lampung is 80.13 and the mean score for IAIM NU Metro lecturers is 77.06. Both means are in the high range. This mean score refers to Arabic language lecturers have the ability to utilize various technological content in the learning process. In addition to technological literacy skills in lecturers, the level of technological literacy among students also needs to be considered. The success of learning with Hybrid Learning model cannot be achieved without the support of students' ability to use technology. The results of data analysis on student technology literacy levels are shown in Table 2.

Table 2. Technology Literacy Level of Students

\begin{tabular}{lrrrrr}
\hline & $\mathrm{N}$ & Minimum & Maximum & Mean & Std. Deviation \\
\hline IAIN Metro Lampung & 50 & 42.00 & 90.00 & 59.9250 & 13.25789 \\
IAIM NU Kota Metro & 50 & 42.00 & 82.00 & 55.1125 & 11.46154 \\
Valid N (listwise) & 50 & & & & \\
\hline
\end{tabular}

From the table 2, it is known that the mean of literacy technology level of IAIN Metro Lampung students is 59.92 and IAIM NU Metro students is 55.11. The mean score of this student's literacy level is at moderate or average level, which means that students at both universities are able to take advantage of technology for learning purposes.

Measurement of the level of technological literacy uses a Likert scale with 5 interval classes, namely very low, low, average, high, and very high with an interval of 1100 values.

Table 3. Measurement scale of Literacy Technology Level

\begin{tabular}{ll}
\hline Interval & Literacy technology level \\
\hline $1-20$ & Very Low \\
$21-40$ & Low \\
$41-60$ & Average \\
$61-80$ & High \\
$81-100$ & Very high \\
\hline
\end{tabular}


The mean score of the literacy level of Arabic lecturers both at IAIN Metro and IAIM NU Metro is in the range of intervals of 61-80 which is on high level. The level of students' technological literacy is in the range of 41-60, which means that the students' technological literacy abilities are average. The development of student abilities can be done simultaneously with the learning process. Lecturers can provide an understanding of the technology content used and how to use hardware and software technology. In addition, lecturers can also explain how to use technology in the online learning process.

The Influence of Using Hybrid Learning Model on Students' Arabic Language Ability

The use of Hybrid Learning model in Arabic learning is able to transform students' Arabic language skills and to increase the positive impact fot student learning attitudes significantly. Before Hybrid Learning is implemented, the students' ability in Arabic is still limited. From the value data obtained, the mean of Arabic language proficiency of IAIM NU Metro is 60.68 and the mean score of IAIN Metro Lampung is 62.23 .

The students' vocabulary mastery increased significantly because Hybrid Learning provided an audio visual learning environment. In the learning process students know a lot of new vocabulary both in learning instructions and in online material content. Apart from improving vocabulary mastery, grammar mastery and reading comprehension also improved significantly. Grammar and reading Arabic texts skills are indicated by the ability to do tasks contained in the material content. The use of Hybrid Learning has also stimulated students' writing skills. The instructions of assignment is given online encourage students to be able to compose words into sentences, sentences into text series. Students' speaking ability is also quite good because what is assigned in online learning is presented orally in offline learning using Arabic.

To find out whether the use of Hybrid Learning is able to transform students' Arabic language skills, the t-test was used. Before the t-test is carried out, the data collected is subjected to a prerequisite test, namely the normality test and the homogeneity test. The results of the normality test with the Kolmogorov-Smirnov test statistic at the significant level $\alpha=5 \%=0.05$. It is known that the calculated sig value of each class is $0.074,0.200,0.084$ and 0.181 respectively. The test decision based on the results of the normality test output obtained all count sig.values $>\alpha$. Then, $\mathrm{H}_{0}$ was accepted. The conclusion of the sample normality test comes from a normally distributed 
population. Furthermore, the homogeneity test was carried out with the Levene test statistic with a significance level: $\alpha=5 \%=0.05$. It is known that the sig.value is $0.974>$ $\alpha$. Then, $\mathrm{H}_{0}$ is accepted, which means that the population variance is homogeneous. Based on the prerequisite test conducted, the sample comes from a population that is normally distributed and the population variance is homogeneous, meaning that the posttest data can be tested by using parametric statistics, namely the t-test. The output results are shown in the table 4.

Table 4. The results of t-test. The Effectiveness of Hybrid Learning Model on Students' Arabic Language Mastery

\begin{tabular}{|c|c|c|c|c|c|c|c|c|c|c|}
\hline \multicolumn{11}{|c|}{ Independent Samples Test } \\
\hline & & \multicolumn{2}{|c|}{$\begin{array}{c}\text { Levene's Test for } \\
\text { Equality of Variances }\end{array}$} & \multicolumn{7}{|c|}{ t-test for Equality of Means } \\
\hline & & \multirow[t]{2}{*}{$\mathrm{F}$} & \multirow[t]{2}{*}{ Sig. } & \multirow[t]{2}{*}{$\mathrm{T}$} & \multirow[t]{2}{*}{ Df } & \multirow[t]{2}{*}{$\begin{array}{l}\text { Sig. (2- } \\
\text { tailed) }\end{array}$} & \multirow{2}{*}{$\begin{array}{c}\text { Mean } \\
\text { Differenc } \\
\mathrm{e}\end{array}$} & \multirow{2}{*}{$\begin{array}{c}\text { Std. Error } \\
\text { Differenc } \\
\mathrm{e}\end{array}$} & \multicolumn{2}{|c|}{$\begin{array}{l}\text { 95\% Confidence Interva } \\
\text { of the Difference }\end{array}$} \\
\hline & & & & & & & & & Lower & Upper \\
\hline \multirow[t]{2}{*}{ Value } & $\begin{array}{l}\text { Equal variances } \\
\text { assumed }\end{array}$ & .161 & .689 & -6.077 & 158 & .000 & -8.73750 & 1.43772 & -11.57713 & -5.89787 \\
\hline & $\begin{array}{l}\text { Equal variances } \\
\text { not assumed }\end{array}$ & & & -6.077 & 157.838 & .000 & -8.73750 & 1.43772 & -11.57715 & -5.89785 \\
\hline
\end{tabular}

The results of the t-test are at the significance level: $\alpha=5 \%=0.05$ with the test result criteria: if $\operatorname{sig}>\alpha, \mathrm{H}_{0}$ is accepted. From table 4, it is known that the sig (2-tailed) value of 0.000 with the decision to test the sig value $<\alpha$. Then, $\mathrm{H}_{0}$ is rejected and $\mathrm{H}_{1}$ is accepted. It means that the use of Hybrid Learning model in Arabic learning is able to increase the Arabic language skills of students.

The results showed that the use of Hybrid Learning model could improve students' mastery of Arabic. The mastery of Arabic is achieved in line with a good implementation of Hybrid Learning procedures. During the process of using Hybrid Learning, the student were paying attention to learning instructions, following the offline learning process by writing things that are considered important, expressing opinions, asking questions and criticizing answers that are deemed inappropriate from colleagues in Arabic. Even though at the initial meeting some students used a mixture of Arabic and Indonesian in expressing their thoughts. In the next meeting, the students already had the courage to speak their minds in Arabic even though they made several wrong sentences.

The use of Hybrid Learning can also improve some of the weaknesses of conventional learning, including limited time in face-to-face meetings ${ }^{21}$. Hybrid Learning model provides satisfaction and comforts to students which have an impact on high 
learning motivation ${ }^{22}$. In addition, Hybrid Learning model can stimulate their teamwork ability among other students in the learning process and make students easier to achieve learning goals ${ }^{23}$.

In online learning, students listen carefully to the audio being played. After that, the students should express in the form of answers to the questions given. Students also read Arabic texts and explain their comprehension in the form of written expressions. Writing activities are important as a measure of student understanding of what is heard and read in the material content provided. Student writing becomes material in answering questions posed by lecturers and becomes a reference in group assignments in face-toface learning activities. In offline and online learning, the lecturer concerns on the various attitudes of students while they are participating in learning activities. The lecturers' notes are used as material to evaluate the process as a reflection for the next activity.

The evaluation process is based not only on lecturers' observations but also on language proficiency tests which include mastery of listening material, the ability to express thoughts through various expressions, the ability to read Arabic texts as measured through reading comprehension and expressing thoughts in writing. Evaluation is conducted by lecturers to measure the level of learning success by using Hybrid Learning. The use of Hybrid Learning model makes the students easier to learn Arabic. Lecturers mentally prepare students to take an active role in learning. Psychological involvement in learning encourages students to determine learning attitudes. Student learning attitudes that show positive respons in participating in Hybrid Learning have an effect on learning outcomes. This is in line with the theory which states that physical and mental strengthening of students is important because students who have good physical and mental health will participate in learning well so that they can show a positive

\footnotetext{
${ }^{21}$ Jason Snart, "Hybrid Learning at the Community College", New Directions for Teaching and Learning Journal 14 (2017): 59-67.

${ }^{22}$ Bryan H. Chen dan Hua Huei Chiou, "Learning Style, Sense of Community and Learning Effectiveness in Hybrid Learning Environment", Interactive Learning Environments 22, no. 4 (2014): 48596.

23 Hao Fan Yang, Yi Ping Phoebe Chen, "Hybrid Deep Learning and Empirical Mode Decomposition Model for Time Series Applications", Expert Systems with Applications 12 (2019): 128-38; Xiaoli Li, S. Dong, \& P. K. Venuvinod, "Hybrid Learning for Tool Wear Monitoring", International Journal of Advanced Manufacturing Technology 16, no. 5 (2000): 303-7; Ron Sun dan Todd Peterson, "Some Experiments with a Hybrid Model for Learning Sequential Decision Making", Information Sciences 11, no. 4 (1998): 83-107; Min Su and Mitra Basu, "A Hybrid Learning System for Image Deblurring", Pattern Recognition Journal, 35, no. 12 (2002): 81-94.
} 
attitude $^{24}$. The combination of offline and online learning is a special attraction for students because the learning materials presented are varied, interesting and accompanied by examples so that the subject matter is easy to understand. The feeling of ease and interest in learning creates high enthusiasm and motivation in students and has a significant effect on Arabic proficiency.

The success of learning by using Hybrid Learning model is mostly determined by the availability of educational infrastructure. The supportive infrastructure determines the success of learning. The infrastructure at IAIN Metro and IAIM NU Metro is really supportive to implement Hybrid Learning. As a process, learning provides a stimulus to students to achieve good language skills. A complete and attractive infrastructure fosters a positive learning attitude for students in Arabic learning. It is important to strengthen a positive learning attitude in students because the absence of a positive learning attitude will have an impact on the learning process that is not conducive which leads to not achieving the standards of competency.

The success of learning Arabic by using Hybrid Learning model can be done if the technology literacy level of the lecturers is adequate. Lecturers, who have good leadership, understand digital literacy, have good emotional intelligence and a high level of cooperation. The importance of adequate literacy levels for lecturers as a prerequisite for being able to implement Hybrid Learning model. This is in line with what Reyna, Rogers, Salaberry and Tsihrintziz explained that the ability of teachers to access, analyze, evaluate and communicate the various informations by using technology is the crucial thing for its implementation of technology-based learning ${ }^{25}$.

As learning facilitators, lecturers must have the ability to take advantage of all learning components in order to be able to create a conducive, easy and enjoyable learning atmosphere. This is in line with what Abazi-Bexheti et al. which explained that technology-based learning requires teachers to have the ability to communicate various information by using technology

\footnotetext{
${ }^{24}$ Nermeen Singer and El Farahaty El Sayed Mahmoud, "Motives of the Egyptian Education Future for Sustainable Development: A comparative analysis between 2020 and 2030", Humanities and Social Sciences Reviews Journal 8, no. 2 (2020): 1-28.

${ }^{25}$ Reyna, Hanham, and Meier, "A framework for Digital Media Literacies for Teaching and Learning in Higher Education", E-Learning and Digital Media 15, no. 4 (2018): 176-190; George A. Tsihrintzis, Dionisios N. Sotiropoulos, dan Lakhmi C. Jain, Machine learning paradigms: Advances in data analytics, Intelligent Systems Reference Library (2019),1-4; Alan Rogers, "Global Media Literacy in a Digital Age: Teaching Beyond Borders", International Review of Education 63, no. 1 (2017): 137-39; M. Rafael Salaberry, "The Use of Technology for Second Language Learning and Teaching: A retrospective", Modern Language Journal 85, no. 1 (2001): 39-56.
} 
effectively in implementing learning through the use of technology ${ }^{26}$. Utilization of technology content in question is technical skills, audio visual skills, critical and social behavior that enable a person to learn, communicate, socialize and contribute in the digital space. Technical skills refer to using computers, software and applications to develop digital content ${ }^{27}$.

The online learning process requires students to be able to use technological features that are used as learning tools. Students who do not have good technological literacy skills become an obstacle for lecturers in implementing learning. Information technology is a very urgent need for educational institutions to train students to be more proficient and knowledgeable through technology ${ }^{28}$.

There are several competencies that teachers must have when they want to integrate information technology in teaching practices, namely (1) basic competence in using hardware and software (2) competence in choosing technology critically in the learning process (3) competence to integrate all technological devices in learning (4) competence to monitor the learning process (5) competence in designing technologybased learning $^{29}$. The ability of technological literacy makes it easy for someone to continue learning to find the latest information which then becomes knowledge ${ }^{30}$. In addition to the ability to use technological devices, technological literacy also concerns the ability to design learning designs using technological literacy ${ }^{31}$. The process of designing literacy components for learning purposes refers to learner characteristics, learning goals, instructional strategies and evaluation procedures ${ }^{32}$.

In using Hybrid Learning model, there are three obstacles. First, students do not have the same level of seriousness in participating in learning. Different learning attitudes can also be seen from the learning tendencies. So the lecturer's assignment gives encouragement to students to be serious in the learning process. Giving encouragement is

${ }^{26}$ Lejla Abazi-Bexheti at.al., Learning and Teaching with Technology in the Knowledge Society. (2018), 37-39.

27 Reyna, Hanham, dan Meier, "A framework for Digital Media Literacies for Teaching and Learning in Higher Education", E-Learning and Digital Media 15, no. 4 (2018): 176-190; Tsihrintzis, Sotiropoulos, and Jain, Machine Learning Paradigms: Advances In Data Analytics, Intelligent Systems Reference Library (2019), 1-4.

${ }^{28}$ Elaheh Yadegaridehkordi dkk., "Decision To Adopt Online Collaborative Learning Tools In Higher Education: A Case Of Top Malaysian Universities", Education and Information Technologies Journal 24, no. 1 (2019): 79-102.

${ }^{29}$ V. Awouters dan S. Jans, "E-Learning Competencies For Teachers In Secondary And Higher Education", International Journal of Emerging Technologies in Learning 4, no. 2 (2009): 58-60.

${ }^{30}$ L. Dee Fink, Editorial, "New Directions for Teaching and Learning", 119 (2009): 1-7.

31 John R. Dakers, Defining Technological Literacy Towards an Epistemological Framework (2006), 1-2.

\footnotetext{
${ }^{32}$ David D. Carbonara, Technology Literacy Applications In Learning Environments (2005), 53-59.
} 
accompanied by rewards and punishments which then have an impact on students' seriousness in learning. Second, in using Hybrid Learning model, the ability of lecturers to design online learning is still limited. So, the portion of the material for mastery of language elements and language skills is not yet balanced. Lecturers' limitations are also related to the design of online learning applications, so it is necessary to involve experts who are expensive and time consuming. The commitment of higher education leaders is needed to budget funds for the development of technology-based learning media. Third, at the same time technology support for students is not completely adequate. The existing technology is still out of date which is sometimes still disturbed by the quality of the signal, picture or sound. In addition, some students cannot follow the information conveyed in online learning because they do not understand the instructions in Arabic. Students who ignore the information will show negative attitudes in learning. In addition, lecturers can evaluate the time allocation in each language material which is adjusted to the level of student knowledge.

This study also differs from previous studies which emphasizes on learning outcomes. This study is oriented by emphasizing the role of students' positive attitudes in the learning process. Providing reinforcement is carried out by lecturers on an ongoing basis in the learning process both offline and online. Reinforcement carried out by the lecturer is in the form of reward and punishment: rewards are given to students who show that their language mastery increases at every meeting, while punishment is given to students who show negative attitudes in learning such as not following the instructions given and not attending classes both offline and online. The lecturer is able to increase attention, motivation, increase learning productivity and increase self-confidence to organize them selves in the learning experience. From this study, it is suggested that Arabic learning in university is more focused on the process that encourages students' positive attitudes in learning. High involvement of positive attitudes in students will encourage learning success.

\section{Conclusion}

This study showed that what has been said so far about learning Arabic is difficult and that students' learning tendency is low, there is no fundamental reason. This study found that positive attitudes in learning increased significantly after using Hybrid Learning model. The improvement in positive attitudes in learning is because the 47 | Jurnal Al Bayan: Jurnal Jurusan Pendidikan Bahasa Arab, 13 (1): 32-52 (2021) 
material in learning activities is designed attractively for both offline and online activities. The high tendency for positive learning attitudes leads to enthusiasm and concentration in following every process in learning. In addition to increasing positive trends in student learning, students' Arabic language skills have also increased. This ability includes mastery of listening, vocabulary and grammar shown in conversation, expressing opinions, reading and writing skills. The use of Hybrid Learning model which is designed according to students' development makes Arabic learning easy and enjoyable. The Hybrid Learning model has been able to answer the problems of learning Arabic for university students. Difficulties caused by low interest in learning, lecturercentered learning, low Arabic proficiency can be overcome by using Hybrid Learning model. The ability to speak Arabic does not only concern academic problems in the learning process, but also concerns psychological conditions that are stimulated by the use of learning technology. Hybrid Learning model in Arabic learning process has fostered a positive attitude in student learning and stimulated student commitment in Arabic learning. The limitation of this study is in the duration of time used in teaching speaking proficiency. In addition, learning evaluation with a quis application model cannot measure speaking ability comprehensively. The speaking ability is evaluated offline which takes a long time. To know in depth about evaluation designs both offline and online, further study is needed as a comparison of several evaluation designs that can measure Arabic language proficiency comprehensively. With this comparison, the level of effectiveness of each learning evaluation design can be tested and a comparative understanding can be obtained. For this reason, this study suggests the need for a followup study that examines the effectiveness of using various online application-based evaluation designs to obtain a comparative and comprehensive understanding.

\section{Acknowledgment}

This research was done with the support of both IAIN Metro Lampung and IAIM NU Metro. For that we would like to thank the Chancellor, Head of the Arabic Language Department, lecturers and students at IAIN Metro and IAIM NU Metro.

\section{References}

Abazi-Bexheti, L., Kadriu, A., Apostolova-Trpkovska, M., Jajaga, E., \& Abazi-Alili, H. "Learning and Teaching with Technology in the Knowledge Society; New 
Literacy, Collaboration and Digital Content".Business Systems Research 9, no. 1 (2018): 978-981.

Awatif, A. R., Hairun Najuwah, J., Ku Fathiyah, K. A., \& Siti Nurhajariah, M. I. "Penguasaan Bahan Bacaan Bahasa Arab Melalui Teknik Membaca SQ3R". Journal of Social Sciences and Humanities (2016): 69-80.

Awouters, V., \& Jans, S. "E-learning Competencies For Teachers In Secondary And Higher Education". International Journal of Emerging Technologies in Learning 4, no. 2 (2009): 58-60.

Azura, W., Ahmad, W., \& Rahman, L. A. Pembelajaran bahasa Arab di Universiti Sains Islam Malaysia ( USIM ): Tinjauan Kecenderungan Pelajar (2007),1-14.

Bala, J., \& Wechsler, H. Shape, "Analysis Using Hybrid Learning". Pattern Recognition 29, no.8 (1996): 1323-1333.

Boccardelli, P., Annosi, M. C., Brunetta, F., \& Magnusson, M. Learning and innovation in Hybrid organizations: Strategic and organizational insights (2017), 9.

Carbonara, D. D. Technology Literacy Applications in Learning Environments, Book, (2005), 53-59.

Astro, R.. "Blended Learning In Higher Education: Trends And Capabilities". Education And Information Technologies 24, no. 4 (2019): 2523-2546.

Chen, B. H., \& Chiou, H. H. "Learning Style, Sense of Community and Learning Effectiveness in Hybrid Learning Environment". Interactive Learning Environments 22, no. 4 (2014): 485-496.

Cremers, P. H. M., Wals, A. E. J., Wesselink, R., \& Mulder, M. "Design Principles For Hybrid Learning Configurations at the Interface Between School And Workplace". Learning Environments Research 19, no. 3 (2016): 309-334.

Dakers, J. R. Defining Technological Literacy Towards An Epistemological Framework (2006), 1-2

Dee Fink, L. New Directions for Teaching and Learning (2009),119.

Dhian, A. "Identifikasi Kesulitan Belajar Siswa Kelas V SD Negeri Sosrowijayan Kota Yogyakarta". Jurnal Pendidikan Guru Sekolah Dasar (2016): 169-182.

Erwhintiana, I., \& Basid, A. "Analisis Diagnostik Kesulitan Belajar Maharah Kalam Mahasiswa Bahasa dan Sastra Arab" (2017): 5.

Fong, J., Au, T., \& Cheung, S. K. S.. "Hybrid Learning With Archived Lectures And Tutorials". International Journal Of Innovation And Learning (2013): 13.

Gilakjani, A. P., \& Sabouri, N. B. "Teachers' Beliefs in English Language Teaching and Learning: A Review of the Literature". English Language Teaching 10, no. 4 (2017).

49 | Jurnal Al Bayan: Jurnal Jurusan Pendidikan Bahasa Arab, 13 (1): 32-52 (2021) 
Hayati, N., \& Wijaya, M. "Pengelolaan Pembelajaran Melalui Blanded Learning Dalam Meningkatkan Receptive Skill Peserta Didik di Pondok Pesantren". Palapa, 6, no. 2 (2018): 1-18.

Haythornthwaite, C., \& Andrews, R. N. L. E-Learning Theory And Practice (2011).

Hj. Yaakub, M. B. "Teaching Arabic as a Second Language: An Evaluation of Key Word Method Effectiveness". Jurnal Teknologi 46, no. 1 (2007).

Ilyas, A. "Dosen Bahasa Arab Dan Kompetensinya". 10, no. 1 (2018): 86-102.

Islam, U., Sunan, N., Makruf, I., \& Arsyad, A. "Implementasi Model Fungsional Dalam Pembelajaran Bahasa Arab di MTs N". AL- Shaut Al- 'Arabiyah (2011): 173-192.

Khadijah, N., Bakar, A., \& Arifin, Z. "Penggunaan Strategi Belajar Bahasa Dalam Pembelajaran Bahasa Arab Sebagai Bahasa Kedua: Satu Sorotan". Prosiding Seminar Pengajaran \& Pembelajaran Bahasa Arab (2014).

Klimova, B. F., \& Kacetl, J. "Hybrid Learning and its Current Role in the Teaching of Foreign Languages". Procedia - Social and Behavioral Sciences (2015): 477-481.

Li, X., Dong, S., \& Venuvinod, P. K.. "Hybrid learning for tool wear monitoring". International Journal of Advanced Manufacturing Technology 16, no. 5 (2000): 303-307.

Linamalini binti Mat Nafi \& Kamarul Shukri bin Mat Teh. "Penggunaan Strategi Pembelajaran Bahasa Arab Sebagai Bahasa Kedua: Satu Kajian Di Institusi Pengajian Tinggi Kelantan". Prosiding Seminar Pengajaran \& Pembelajaran Bahasa Arab (2014).

Maghfirah, A. F. "Kreativitas Dosen dalam Meningkatkan Minat Belajar Bahasa Arab Mahasiswa di IAIN Surakarta". Academica Journal of Multidisciplinary Studies (2017): 19-33.

Manian, C. "Designing Student Oriented Elearning Environments in Higher Education to Match Technological Trends". International Journal on Integrating Technology in Education 2 no. 3 (2013): 1-11.

Mastura Arshad, \& Kaseh Abu Bakar. "Penggunaan Strategi Pembelajaran Kemahiran Bertutur Bahasa Arab: Kajian Di Pusat Asasi UIAM". Persidangan Kebangsaan Pengajaran Dan Pembelajaran Bahasa Arab 2012 (PKEBAR'12), Prosiding (2012).

Mei, S. Y., Ju, S. Y., \& Mohd, A. B. "Cooperative Learning Strategy in teaching Arabic for Non Native Speakers". European Journal of Social Sciences Education and Research 11, no. 2 (2017): 261.

Mufidah, N., Salamah, U., Muthoharoh, I., \& Irfan Islamy, M. "Hybrid Learning Dalam Pembelajaran Kosa Kata Bahasa Arab pada Anak Berbantuan Media Al-Mutho". Journal AL-MUDARRIS, 2, no. 1 (2019): 40. 
Mustari, M. I., Jasmi, K. A., Muhammad, A., \& Yahya, R. "Model Pengajaran dan Pembelajaran Bahasa Arab". Seminar Antarabangsa Perguruan Dan Pendidikan Islam [SEAPPI2012]. Prosiding (2012).

Nasution, S., \& Zulheddi, Z. "Pengembangan Model Pembelajaran Bahasa Arab Berbasis Teori Konstruktivisme Di Perguruan Tinggi". Arabi : Journal of Arabic Studies 3, no. 2 (2018): 121.

Raes, A., Detienne, L., Windey, I., \& Depaepe, F. "A Systematic Literature Review On Synchronous Hybrid Learning: Gaps Identified". Learning Environments Research (2019).

Reyna, J., Hanham, J., \& Meier, P. C. "A Framework For Digital Media Literacies For Teaching And Learning In Higher Education". E-Learning and Digital Media, 15, no. 4 (2018): 176-190.

Rogers, A. "Global Media Literacy In A Digital Age: Teaching Beyond Borders". International Review Of Education, 63, no. 1 (2017): 137-139.

Ross, V., Murphy, C., MacNeill, A., \& Masson, "A. Hybrid Learning Model-A Framework for Teaching and Learning Practice". International Journal of Emerging Technologies in Learning 3, no. 1 (2008): 12-17.

Salaberry, M. R. "The Use Of Technology For Second Language Learning And Teaching: A Retrospective". Modern Language Journal 85, no. 1 (2001): 39-56.

Setyaningrum, W. "Blended Learning: Does It Help Students In Understanding Mathematical Concepts?". Jurnal Riset Pendidikan Matematika 5, no. 2 (2018): 244-253.

Singer, N., \& Mahmoud, E. F. E. S. "Motives Of The Egyptian Education Future For Sustainable Development: A Comparative Analysis Between 2020 And 2030". Humanities And Social Sciences Reviews, 8, no. 2 (2020): 1-28.

Snart, J. "Hybrid Learning at the Community College". New Directions for Teaching and Learning (2017): 59-67.

Su, M., \& Basu, M. "A Hybrid Learning System For Image Deblurring". Pattern Recognition 35, no. 12 (2002): 2881-2894.

Subur, S. "Model dan Strategi Pembelajaran Bahasa Arab". INSANIA : Jurnal Pemikiran Alternatif Kependidikan 11, no. 2 (1970): 164-175.

Sun, R., \& Peterson, T. "Some Experiments With A Hybrid Model For Learning Sequential Decision Making". Information Sciences 11, no. 4 (1998): 83-107.

Supardi, S. "Model Pembelajaran Bahasa Arab Terpadu di Perguruan Tinggi Keagamaan Islam Negeri". LISANIA: Journal of Arabic Education and Literature 2, no. 1 (2018): 13 .

Tajuddin, S. "Pengembangan Model Pembelajaran Bahasa Arab". Jurnal Perameter 29, 51 | Jurnal Al Bayan: Jurnal Jurusan Pendidikan Bahasa Arab, 13 (1): 32-52 (2021) 
no. 2 (2016): 200-215.

Tanguma, J., Liu, L. C., Koong, K. S., \& Tanguma, J. "Hybrid learning and effects on student assessment outcomes". International Journal of Mobile Learning and Organisation 2, no. 1 (2008): 36-47.

Thorne, K. Blended Learning: How to Intergrate Online Learning and Traditional Learning. In Kogan (2003).

Tsihrintzis, G. A., Sotiropoulos, D. N., \& Jain, L. C. "Machine learning paradigms: Advances in data analytics". Intelligent Systems Reference Library 149 (2019).

Wang, F. L., Fong, J., \& Kwan, R. C. Handbook of Research on Hybrid Learning Models: Advanced Tools, Technologies, and Applications (2009).

Wekke, I. S. "Arabic Teaching and Learning: A Model from Indonesian Muslim Minority". Procedia - Social and Behavioral Sciences 191 (2015): 286-290.

Yadegaridehkordi, E., Shuib, L., Nilashi, M., \& Asadi, S. "Decision to Adopt Online Collaborative Learning Tools in Higher Education: A Case of Top Malaysian Universities".Education and Information Technologies 24, no. 1 (2019): 79-102.

Yang, H. F., \& Chen, Y. P. P. "Hybrid Deep Learning And Empirical Mode Decomposition Model For Time Series Applications". Expert Systems With Applications (2019): 128-138.

Yaqub, M. T. "Developing Speaking Skill in Arabic Learners : A Proposal for Integration of Product and Process Approaches". European Scientific Jounal 8, no. 29 (2012): 140-149.

Yen, S. C., Lo, Y., Lee, A., \& Enriquez, J. M. "Learning Online, Offline, And InBetween: Comparing Student Academic Outcomes And Course Satisfaction In Face-To-Face, Online, And Blended Teaching Modalities". Education and Information Technologies Journal 23, no. 5 (2018): 2141-2153.

Zamri, A., \& Ibtisam, A. "Metode Pengajaran dan Pembelajaran Bahasa Arab Berasaskan Empat Kemahiran". Prosiding Seminar Pengajaran \& Pembelajaran Bahasa Arab (2014). 